\title{
$\alpha$-AMYLASE ACTIVITY IN FREEZE-DRIED AND SPRAY-DRIED HONEY
}

\author{
*Anete Keke, Ingmars Cinkmanis \\ Latvia University of Life Sciences and Technologies, Latvia \\ *Corresponding author's email: anete.keke@1lu.lv
}

\begin{abstract}
Honey is a naturally supersaturated sugar solution, which tends to crystallize. The crystallization of honey can lead to unwanted fermentation that can have a negative impact to honey quality. The production of honey powder could be an alternative method to prevent honey from fermentation. Honey powder could be used as alternative substitute to liquid honey that would allow to use this product more widely in the food industry. $\alpha$-amylase activity is one of the most important parameters to evaluate the quality of honey. The aim of this study was to investigate the effect of freeze-drying and spray-drying on honey $\alpha$-amylase activity. Detection of $\alpha$-amylase activity was carried out by spectrophotometric method. High-performance liquid chromatography was used to determine the content of hydroxymethylfurfural in the powders. The obtained results showed that both drying methods had a negative impact to the enzyme activity in the samples. The lowest activity of $\alpha$-amylase $(8.3 \mathrm{DN})$ was measured in the spray-dried honey powder. Concentration of hydroxymethylfurfural (HMF) in the powders did not exceed required concentration $40 \mathrm{mg} \mathrm{kg}^{-1}$.
\end{abstract}

Key words: $\alpha$-amylase activity, freeze drying, spray drying, honey, HMF.

\section{Introduction}

Honey is well-known food product over the world due to its sweet taste, aroma, and health benefits. Moreover, honey is chemically complex food product, which consists of approximately 200 substances (Geana \& Ciucure, 2020). Fructose and glucose are the main constituents of honey. There is also a wide range of minor components that are present in honey such as enzymes, organic acids, amino acids, phenolic compounds, etc. Honey quality and chemical composition depend on the floral and geographical origin, climate and processing (Sakač et al., 2018).

As a supersaturated sugar solution, honey tends to spontaneously crystallize. The spontaneous crystallization of honey increases water activity, which can lead to unwanted fermentation (Tappi et al., 2019). The unwanted fermentation can negatively affect the quality of honey. Thermal processing is often used to prevent the negative effect of crystallization (Tosi et al., 2004; Ribeiro et al., 2018). Thermal methods could be used to transform liquid honey into powdered honey by drying. This is an alternative method that could be used to preserve honey. Moreover, powdered honey has many advantages such as ease of packaging and handling, prolonged shelf life, expanded usage in the food industry (Kılınç \& Demir, 2017). The production of honey in a powdered form is challenging due to its high concentration of sugars and organic acids. Sugarrich products such as honey tends to form lumps or syrup during the drying process (Samborska, 2019). Different drying aids such as maltodextrin, whey protein isolate, Arabic gum are added to honey to increase the glass transition temperatures (Shi, Fang, \& Bhandari, 2013; Muzaffar, 2015). The concentration of drying aids in honey powder cannot be lower than $50 \%$ of solids to successfully perform the drying of honey (Bhandari, Datta, \& Howes, 1997). Samborska and co-workers (Samborska, Sokołowska, \& Szulc, 2017a) reported that pre-treatment methods such as diafiltration can be used to obtain powder, which contains $75 \%$ of honey.

Dehydrated honey can be produced by vacuum drying, microwave vacuum drying, freeze-drying and spray drying (Cui et al., 2008; Nurhadi \& Roos, 2016; Sramek et al., 2016). Spray drying is widely used to obtain honey powder. The method is very popular due to its cost effectiveness, short production time and high product quality (Jedlińska et al., 2019; Samborska, 2019). Freeze-drying is an especially useful drying technique to preserve bioactive compounds. Unfortunately, due to the methods expensiveness and long production time, freeze-drying is rarely used to produce honey powder (Subramanian, Hebbar, \& Rastogi, 2007).

Enzymatic activity is an important indicator to evaluate the quality of honey. Enzymes are very sensitive to thermal processing, which can lead to loss of enzymatic activity of honey (Kowalski \& Lukasiewicz, 2017). $\alpha$-amylase, which is predominant enzyme in honey, can be inactivated by thermal treatments at $80{ }^{\circ} \mathrm{C}$ for 1.2 hours (Schade, Marsh, \& Eckert, 1958; Tosi et al., 2004). $\alpha$-amylase (diastase) activity is the main indicator to evaluate the quality of honey as well as authenticity. According to the Council of the European Union Directive relating to honey $2001 / 110 / \mathrm{EC}, \alpha$-amylase activity is required not to be lower than $8 \mathrm{DN}$. Diastase number (DN) in Schade scale is defined as grams of starch hydrolysed during one hour at $40{ }^{\circ} \mathrm{C}$ (Kowalski et al., 2012). Hydroxymethylfurfural is another important indicator that is used along with $\alpha$-amylase activity to evaluate the quality of honey (Pasias, Kiriakou, \& Proestos, 2017).

The aim of this study was to investigate the effect of freeze-drying and spray-drying on honey $\alpha$-amylase activity. 


\section{Chemical composition of multifloral honey}

\begin{tabular}{|c|c|c|c|c|c|c|}
\hline $\begin{array}{l}\text { Free acidity, } \\
\text { meq kg-1 }\end{array}$ & $\mathrm{pH}$ & $\begin{array}{c}\text { Moisture content, } \\
\%\end{array}$ & $\begin{array}{c}\alpha \text {-amylase activity, } \\
\text { DN }\end{array}$ & 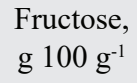 & $\begin{array}{l}\text { Glucose, } \\
\text { g } 100 \mathrm{~g}^{-1}\end{array}$ & $\begin{array}{l}\mathrm{HMF} \\
\mathrm{mg} \mathrm{kg}^{-1}\end{array}$ \\
\hline $42.0 \pm 1.0$ & $3.66 \pm 0.01$ & $20.5 \pm 0.2$ & $18.5 \pm 0.3$ & $36.4 \pm 0.2$ & $31.8 \pm 0.2$ & $41.4 \pm 0.5$ \\
\hline
\end{tabular}

\section{Materials and Methods}

The research was carried out in the scientific laboratory of Natural compounds and the scientific laboratory of Food processing engineering at the Faculty of Food Technology, the Latvia University of Life Sciences and Technologies.

Multifloral honey sample was delivered by the Latvian beekeeper of southern Latvia. The production year of honey was 2018. The main characteristic properties of the honey sample are shown in Table 1.

Maltodextrin (STAR-DRI ${ }^{\circledR} 10$ NG, TATE \& LYLE) was supplied by a local company (BANG \& BONSOMER LATVIA, Rīga, Latvia). Dextrose equivalent (DE) of maltodextrin was 10.4, and moisture content was $4.3 \%$. Maltodextrin was used as a carrier.

Obtaining freeze-dried and spray-dried honey

$20 \%$ aqueous solutions of honey with maltodextrin were prepared for freeze-drying and spray-drying experiments. The ratio of honey and maltodextrin in the solutions was 1:2.

Freeze-drying of honey solution: the prepared solution was poured into a plastic freezer box, where the thickness of solution was approximately one centimetre. The freezer box was placed in the freezer for 2 hours at $-20 \pm 1{ }^{\circ} \mathrm{C}$. After 2 hours, the frozen sample was transferred to a freezedryer ALPHA 1-2 LDplus (MARTIN CHRIST Gefriertrocknungsanlagen $\mathrm{GmbH}$, Germany). The freeze-drying process was performed under following conditions: the temperature of condenser was set to $-50.6 \pm 0.5{ }^{\circ} \mathrm{C}$ and the pressure was 0.036 mbar. The duration of lyophilisation was 72 hours.

Spray-drying of honey solution: the prepared honey solution was spray-dried in BÜCHI mini spray drier B-290 (Labortechnik AG, Switzerland). The spray-drying process was carried out under following condition: the inlet air temperature was set to $180{ }^{\circ} \mathrm{C}$, outlet temperature was $80^{\circ} \mathrm{C}$, sample speed rate was $15 \mathrm{~mL} \mathrm{~min}^{-1}$.

After drying, the obtained powders were collected in polyethylene bags and stored in the dark and dry place at temperature of $20^{\circ} \mathrm{C}$ until further analysis.

\section{Determination of moisture content}

One gram of obtained powders was weighted on glass fibre sheets and placed on the sample pan of moisture analyzer AND MX-50 (A\&D Company, Limited, Japan). The moisture analysis was carried out by heating up the samples at a drying temperature of $140{ }^{\circ} \mathrm{C}$, the duration of analysis was 20 minutes. Moisture data was recorded using the software 'WinCT-Moisture'.

Determination of $\alpha$-amylase activity

$\alpha$-amylase activity was evaluated in liquid honey sample and obtained honey powders. The determination of $\alpha$-amylase activity was performed by Amylazyme assay procedure (Megazyme, Ireland). The samples for analysis were prepared according to Amylazyme assay procedure. The absorbance of the analysed samples was measured by spectrophotometer Jenway 6405 UV/Vis (JENWAY, the U.K.) at $590 \mathrm{~nm}$ wavelength. The activity of the enzyme was calculated using the following formula:

$$
\text { Schadeunits }=20.0 \times \Delta A b s
$$

where: is the absorbance of the sample at $590 \mathrm{~nm}$.

Determination of hydroxymethylfurfural

The concentration of hydroxymethylfurfural was detected by high-performance liquid chromatography (HPLC). Honey and honey powder solutions were prepared at a concentration of $50 \mathrm{~g} \mathrm{~L}^{-1}$. The analysis of the samples was performed using an analytical column PerkinElmer C18 (4.6 mm × $250 \mathrm{~mm}$ I.D., particle size $5 \mathrm{~mm}$ ). The temperature of column and detector for the analysis was set to $25^{\circ} \mathrm{C}$. The mixture of acetonitrile (HPLC grade, Sigma-Aldrich) and deionized water (HPLC grade) was used as a mobile phase. The ratio of acetonitrile and deionized water was 10:90 (v/v). The analysis of the samples was carried out under isocratic conditions. Flow rate was $1.3 \mathrm{~mL} \mathrm{~min}^{-1}$. The volume of the sample injection was $10 \mu \mathrm{L}$, which was performed by autosampler SIL20A. Detection of hydroxymethylfurfural carried out at $280 \mathrm{~nm}$ wavelength. The analysis was performed on Shimadzu LC-20 Prominence liquid chromatograph (Shimadzu USA Manufacturing Inc, Canby, USA) with a Shimadzu DAD SPD-M20A detector.

Determination of fructose and glucose content

Honey and honey powder solutions were prepared at a concentration of $50 \mathrm{~g} \mathrm{~L}^{-1}$ to evaluate the content of fructose and glucose. The analysis of the sample was performed on Shimadzu LC-20 Prominence liquid chromatograph. The analytical column SUPELCOSIL $^{\mathrm{TM}} \mathrm{LC}^{\mathrm{N} H} \mathrm{NH}_{2}(4.6 \mathrm{~mm} \times 250 \mathrm{~mm}$ I.D., particle size $5 \mathrm{~mm})$. The temperature of column and detector was set to $30^{\circ} \mathrm{C}$. The mixture of acetonitrile 
(HPLC grade, Sigma-Aldrich) and deionized water (HPLC grade) was used as a mobile phase. The ratio of acetonitrile and deionized water was 80:20 (v/v). The detection of glucose and fructose was performed under isocratic conditions. Flow rate was $1 \mathrm{~mL} \mathrm{~min}^{-1}$. Injection volume of $10 \mu \mathrm{L}$ was performed using an autosampler SIL-20A. Shimadzu RID 10A Refractive Index detector was used to detect the presence of fructose and glucose in the samples.

\section{Statistical analysis}

All experiments were repeated in three replications. The obtained data of the research was expressed as the mean \pm standard deviation. The data was assessed by analysis of variance (ANOVA) and compared by Tukey comparison test $(\mathrm{p}<0.05)$. The statistical analysis was carried out using Microsoft Office Excel 2016.

\section{Results and Discussion}

In this research, dehydration of honey was performed by two methods. One of the drying technique was freeze-drying, which is widely used in pharmaceutics due to its ability to preserve bioactive compounds (Nascimento et al., 2015). Another drying method, which was used to obtained dehydrated honey, was spray-drying. Spray-drying is one of the most common techniques to obtain honey-rich powders (Samborska, Gajek, \& Kamińska-Dwórznicka, 2015). In this study, the drying experiments of $20 \%$ honey solutions with maltodextrin resulted in honey-rich powders. The moisture content in the honey powder, which was obtained by freeze-drying, was $5.3 \%$ and in the honey powder, which was obtained by spraydrying, was $4.8 \%$. Maltodextrin is mainly used for drying sugar and acid rich food products (Umesh Hebbar, Rastogi, \& Subramanian, 2008). It has a high molecular weight, which helps to increase the glass temperature of drying particles and reduces hygroscopicity. Nurhardi and co-workers also used maltodextrin (1:1) in their study of obtaining honey powder by spray-drying and vacuum drying methods. The moisture content in the spray-dried honey powder was $2.3 \%$, but in the vacuum-dried powder it was 1.0\% (Nurhadi et al., 2012). Sramek and co-authors obtained honey-rich powder by the freeze-drying method. In this study, honey was mixed with glucose syrup to prepare the powder. The moisture content in the final product was 3.1\% (Sramek et al., 2016). Our results and other researchers' studies showed that moisture content could be reduced by choosing different drying aids and changing the ratio of honey and drying aids in solutions.

$\alpha$-amylase activity was detected to evaluate the quality of obtained powders. The value of diastase number in both dehydrated honey samples was not lower than 8 (Figure 1).

The lowest enzymatic activity was presented in the spray-dried honey, where the value of diastase number was $8.3 \pm 0.2$. During the spray-drying, the water of the solution was removed, which resulted in degradation of molecules and loss of enzymatic activity. Samborska and co-workers (Samborska et

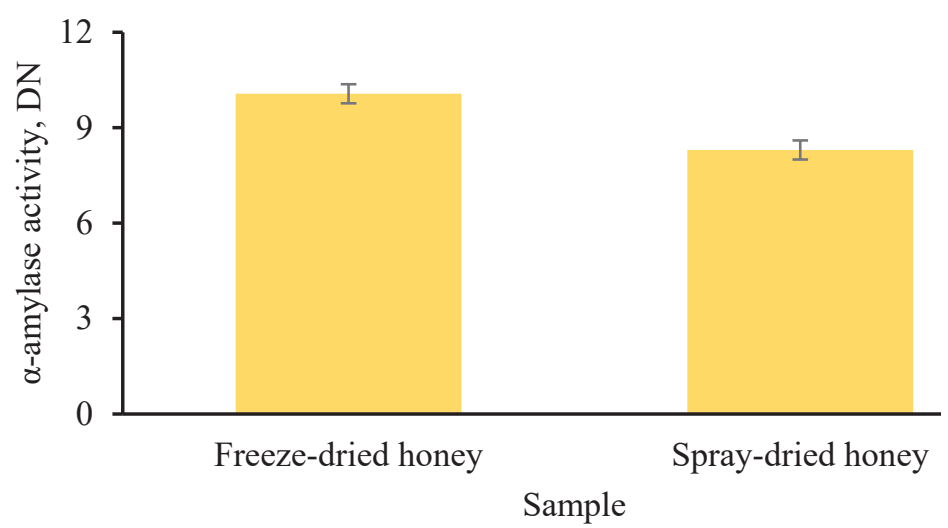

Figure 1. $\alpha$-amylase activity in freeze-dried and spray-dried honey samples.

\section{Content of HMF, fructose, and glucose in dehydrated honey}

\begin{tabular}{|c|c|c|c|}
\hline Sample & $\begin{array}{l}\text { HMF, } \\
\mathrm{mg} \mathrm{kg}^{-1}\end{array}$ & $\begin{array}{l}\text { Fructose, } \\
\text { g } 100 \mathrm{~g}^{-1}\end{array}$ & $\begin{array}{l}\text { Glucose, } \\
\text { g } 100 \mathrm{~g}^{-1}\end{array}$ \\
\hline Freeze-dried honey & $28.1 \pm 0.2$ & $16.7 \pm 0.3$ & $9.2 \pm 0.4$ \\
\hline Spray-dried honey & $36.5 \pm 0.3$ & $16.5 \pm 0.2$ & $9.5 \pm 0.5$ \\
\hline
\end{tabular}


al., 2017b), who obtained honey powder using spray drying method, reported that $\alpha$-amylase (diastase) activity in their product was $10.9 \pm 0.2 \mathrm{DN}$. They also pointed out that the enzymatic activity in the honey powder was lower than it was in fresh honey $(14.4 \pm 0.2 \mathrm{DN})$. Freeze-dried honey sample showed higher $\alpha$-amylase activity than the spray-dried sample. The value of $\alpha$-amylase activity in the freezedried sample was $10.0 \pm 0.3 \mathrm{DN}$. The obtained results on $\alpha$-amylase activity showed that freeze-drying is more gentle drying technique than spray-drying. Unfortunately, there are lack of literature data on $\alpha$-amylase activity changes during the freeze-drying process that could be used to compare our obtained results. The concentration of hydroxymethylfurfural (HMF) was detected in obtained dehydrated honey samples (Table 2).

The powder, which was produced using a spray dryer, had higher concentration of HMF than the powder that was obtained by freeze-drying. The concentration of HMF in the spray-dried honey was $36.5 \pm 0.3 \mathrm{mg} \mathrm{kg}^{-1}$ and in the freeze-dried honey it was $28.1 \pm 0.2 \mathrm{mg} \mathrm{kg}^{-1}$. The obtained results showed that the used drying method significantly $(\mathrm{p}<0.05)$ impacts the concentration of HMF in the product. Hydroxymethylfurfural is formed during dehydration of monosaccharides (fructose and glucose) and/ or during the Maillard reaction (Kowalski \& Lukasiewicz, 2017; Shapla et al., 2018). The formation of hydroxymethylfurfural also depends on the factors such as $\mathrm{pH}$, free acidity, temperature etc (Kowalski et al., 2013). As high temperatures (inlet air temperature: $180^{\circ} \mathrm{C}$; outlet air temperature: $80^{\circ} \mathrm{C}$ ) were used during the spray-drying process, it caused the increase of the content of hydroxymethylfurfural in the final product. The high temperature in the spray drying process and low $\mathrm{pH}$ of multifloral honey $(\mathrm{pH}=3.66 \pm 0.01)$ were the catalysts of the formation of hydroxymethylfurfural (Shapla et al., 2018). The statistical analysis of the obtained data showed that the chosen drying methods did not impact the content of fructose $(p>0.05)$ and glucose $(p>0.05)$ in the honey powder.

The further studies should be focused on the obtaining of honey powder by freeze-drying. Freezedrying is a gentle drying method, which preserves bioactive compounds and allows to produce highquality food products (Karam et al., 2016). The method should be modified to improve the quality of honey powders. The method could be used as an alternative method to obtain high quality honey-rich powder in the food industry. The obtained results showed that the used drying method impacts two important quality parameters $\alpha$-amylase activity and the concentration of hydroxymethylfurfural in the honey-rich powder.

\section{Conclusions}

The obtained results showed that freeze-drying and spray drying can be used to obtain honeyrich powders. $\alpha$-amylase activity in both powders decreased during the drying process. Freeze-dried honey powder had better quality as $\alpha$-amylase activity was higher and the content of hydroxymethylfurfural was lower than spray-dried honey powder.

\section{Acknowledgements}

This research was supported by the Latvia University of Life Sciences and Technologies' project 'Strengthening Research Capacity in the Latvia University of Life Sciences and Technologies'. Project No. 3.2-10/2019/LLU/140. The authors would like to thank to Dr. sc. ing. Igors Šepel̦evs for sharing his knowledge and experience during the spray drying experiments.

\section{References}

Bhandari, B.R., Datta, N., \& Howes, T. (1997). Problems associated with spray drying of sugar-rich foods. Drying Technology, 15(2), 671-684. DOI: 10.1080/07373939708917253.

Cui, Z.W., Sun, L.J., Chen, W., \& Sun, D.W. (2008). Preparation of dry honey by microwave-vacuum drying. Journal of Food Engineering, 84(4), 582-590. DOI: 10.1016/j.jfoodeng.2007.06.027.

The Council of the European Union. (2002). Directive relating to honey 2001/110/EC.

Geana, E.I., \& Ciucure, C.T. (2020). Establishing authenticity of honey via comprehensive Romanian honey analysis. Food Chemistry, 306(September 2019), 125595. DOI: 10.1016/j.foodchem.2019.125595.

Jedlińska, A., Samborska, K., Wieczorek, A., Wiktor, A., Ostrowska-Ligęza, E., Jamróz, W., ... WitrowaRajchert, D. (2019). The application of dehumidified air in rapeseed and honeydew honey spray drying Process performance and powders properties considerations. Journal of Food Engineering, 245(July 2018), 80-87. DOI: 10.1016/j.jfoodeng.2018.10.017.

Karam, M.C., Petit, J., Zimmer, D., Baudelaire Djantou, E., \& Scher, J. (2016). Effects of drying and grinding in production of fruit and vegetable powders: A review. Journal of Food Engineering, 188, 32-49. DOI: 10.1016/j.jfoodeng.2016.05.001.

Kılınç, M., \& Demir, K.M. (2017). The Facilities of Spray Dried Honey Powder Use As a Substitute for Sugar in Cookie Production. Journal of Food and Health Science, 3(2), 67-74. DOI: 10.3153/JFHS17009. 
Kowalski, S., \& Lukasiewicz, M. (2017). Diastase and Invertase Activity Changes and 5-Hydroxymethyl2-Furfural Formation in Honeys Under Influence of Microwave Irradiation. Journal of Food Process Engineering, 40(2). DOI: 10.1111/jfpe.12410.

Kowalski, S., Lukasiewicz, M., Bednarz, S., \& Panus, M. (2012). Diastase number changes during thermaland microwave processing of honey. Czech Journal of Food Sciences, 30(1), 21-26. DOI: 10.17221/123/2010cjfs.

Kowalski, S., Lukasiewicz, M., Duda-Chodak, A., \& Zięc, G. (2013). 5-hydroxymethyl-2-furfural (HMF) heat-induced formation, occurrence in food and biotransformation - A review. Polish Journal of Food and Nutrition Sciences, 63(4), 207-225. DOI: 10.2478/v10222-012-0082-4.

Muzaffar, K. (2015). Stickiness Problem Associated with Spray Drying of Sugar and Acid Rich Foods: A Mini Review. Journal of Nutrition \& Food Sciences, s12(August), 10-13. DOI: 10.4172/2155-9600.s12-003.

Nascimento, A.P., Moraes, L.A.R., Ferreira, N.U., DePadua Moreno, G., Uahib, F.G.M., Barizon, E.A., \& Berretta, A.A. (2015). The lyophilization process maintains the chemical and biological characteristics of royal jelly. Evidence-Based Complementary and Alternative Medicine, 2015, 8-12. DOI: 10.1155/2015/825068.

Nurhadi, B., Andoyo, R., Mahani, \& Indiarto, R. (2012). Study the properties of honey powder produced from spray drying and vacuum drying method. International Food Research Journal, 19(3), 907-912. DOI: 10.1093/jeg/4.2.219.

Nurhadi, B., \& Roos, Y.H. (2016). Dynamic water sorption for the study of amorphous content of vacuum-dried honey powder. Powder Technology, 301, 981-988. DOI: 10.1016/j.powtec.2016.07.055.

Pasias, I.N., Kiriakou, I.K., \& Proestos, C. (2017). HMF and diastase activity in honeys: A fully validated approach and a chemometric analysis for identification of honey freshness and adulteration. Food Chemistry, 229, 425-431. DOI: 10.1016/j.foodchem.2017.02.084.

Ribeiro, G.P., Villas-Bôas, J.K., Spinosa, W.A., \& Prudencio, S.H. (2018). Influence of freezing, pasteurization and maturation on Tiúba honey quality. LWT - Food Science and Technology, 90(July 2017), 607-612. DOI: 10.1016/j.lwt.2017.12.072.

Sakač, M.B., Jovanov, P.T., Marić, A.Z., Pezo, L.L., Kevrešan, Ž.S., Novaković, A.R., \& Nedeljković, N.M. (2018). Physicochemical properties and mineral content of honey samples from Vojvodina (Republic of Serbia). Food Chemistry, 276, 15-21. DOI: 10.1016/j.foodchem.2018.09.149.

Samborska, K. (2019). Powdered honey - drying methods and parameters, types of carriers and drying aids, physicochemical properties and storage stability. Trends in Food Science and Technology, 88(May 2017), 133-142. DOI: 10.1016/j.tifs.2019.03.019.

Samborska, K., Gajek, P., \& Kamińska-Dwórznicka, A. (2015). Spray drying of honey: The effect of drying agents on powder properties. Polish Journal of Food and Nutrition Sciences, 65(2), 109-118. DOI: 10.2478/pjfns-2013-0012.

Samborska, K., Sokołowska, P., \& Szulc, K. (2017a). Diafiltration and agglomeration as methods to improve the properties of honey powder obtained by spray drying. Innovative Food Science and Emerging Technologies, 39, 33-41. DOI: 10.1016/j.ifset.2016.10.002.

Samborska, K., Wasilewska, A., Gondek, E., Jakubczyk, E., \& Kamińska-Dwórznicka, A. (2017b). Diastase Activity Retention and Physical Properties of Honey/Arabic Gum Mixtures after Spray Drying and Storage. In International Journal of Food Engineering (Vol. 13), Walter de Gruyter GmbH. DOI: 10.1515/ ijfe-2016-0320.

Schade, J.E., Marsh, G.L., \& Eckert, J.E. (1958). Diastase activity and hydroxy-methyl-furfural in honey and their usefulness in detecting heat alteration. Journal of Food Science, 23(5), 446-463. DOI: 10.1111/ j.1365-2621.1958.tb17592.x.

Shapla, U.M., Solayman, M., Alam, N., Khalil, M.I., \& Gan, S.H. (2018, December 4). 5-Hydroxymethylfurfural (HMF) levels in honey and other food products: effects on bees and human health. Chemistry Central Journal. DOI: 10.1186/s13065-018-0408-3.

Shi, Q., Fang, Z., \& Bhandari, B. (2013). Effect of Addition of Whey Protein Isolate on Spray-Drying Behavior of Honey with Maltodextrin as a Carrier Material. Drying Technology, 31(13-14), 1681-1692. DOI: 10.1080/07373937.2013.783593.

Sramek, M., Woerz, B., Horn, H., Weiss, J., \& Kohlus, R. (2016). Preparation of High-Grade Powders from Honey-Glucose Syrup Formulations by Vacuum Foam-Drying Method. Journal of Food Processing and Preservation, 40(4), 790-797. DOI: 10.1111/jfpp.12660.

Subramanian, R., Hebbar, H.U., \& Rastogi, N.K. (2007). Processing of honey: A review. International Journal of Food Properties, 10(1), 127-143. DOI: 10.1080/10942910600981708. 
Tappi, S., Laghi, L., Dettori, A., Piana, L., Ragni, L., \& Rocculi, P. (2019). Investigation of water state during induced crystallization of honey. Food Chemistry, 294(January), 260-266. DOI: 10.1016/j. foodchem.2019.05.047.

Tosi, E.A., Ré, E., Lucero, H., \& Bulacio, L. (2004). Effect of honey high-temperature short-time heating on parameters related to quality, crystallisation phenomena and fungal inhibition. LWT - Food Science and Technology, 37(6), 669-678. DOI: 10.1016/j.lwt.2004.02.005.

Umesh Hebbar, H., Rastogi, N.K., \& Subramanian, R. (2008). Properties of Dried and Intermediate Moisture Honey Products: A Review. International Journal of Food Properties, 11(4), 804-819. DOI: 10.1080/10942910701624736. 